\title{
KONSEP DASAR EVALUASI DAN IMPLIKASINYA DALAM EVALUASI PEMBELAJARAN PENDIDIKAN AGAMA ISLAM DI SEKOLAH
}

\author{
Tatang Hidayat ${ }^{1}$ Abas Asyafah ${ }^{2}$ \\ tatanghidayat@upi.edu ${ }^{1}$ \\ Universitas Pendidikan Indonesia, Bandung Jawa Barat ${ }^{1,2}$
}

\begin{abstract}
This paper aims to discover the basic concepts of evaluation and its implications on evaluating Islamic Religious Education learning in Schools. This paper employs a qualitative approach and literature study method. Based on the results of the discussion, the evaluation consisted of measurement and assessment. In the context of learning, evaluation has a very important and strategic position since it is included in the steps of learning. The aim is to determine the effectiveness and efficiency of the learning system. The area of discussion includes evaluation in learning programs, learning processes, and learning outcomes. In general, the principle of evaluation consists of continuity, comprehensiveness, fairness, objectivity, cooperativeness, and practicality. In specific, the principle consists of integration, coherence, pedagogical, and accountability. In terms of type, learning evaluation consists of evaluation of planning, development, monitoring, impact, efficiency, and comprehensive programs. In terms of object, evaluation of learning includes input, transformation, and output. The subject includes the educator, the officer who has been trained, and the students that can evaluate themselves. In terms of the technique, it consists of tests and non-tests. The implication is that the evaluation of the learning of Islamic Religious Education in schools needs to be carried out in a continuous, comprehensive and integrated manner. Thus, Islamic Religious Education educators must be able to evaluate the development of students, including in the aspects of aqliyah, qolbiyah, and amāliyah.
\end{abstract}

Keywords: Evaluation, Learning, Islamic Religious Education, Schools

\begin{abstract}
Abstrak
Tulisan ini bertujuan untuk mengetahui konsep dasar evaluasi dan implikasinya dalam evaluasi pembelajaran Pendidikan Agama Islam di Sekolah. Tulisan ini menggunakan pendekatan kualitatif dan metode studi literatur. Berdasarkan hasil pembahasan, evaluasi terdiri dari pengukuran dan penilaian. Dalam konteks pembelajaran, evaluasi memiliki kedudukan yang sangat penting dan strategis, karena termasuk dalam langkah-langkah pembelajaran. Tujuannya untuk mengetahui efektivitas dan efisiensi sistem pembelajaran. Ruang lingkunya mencakup evaluasi dalam program pembelajaran, proses pembelajaran, dan hasil pembelajaran. Secara umum, prinsip evaluasi terdiri dari kontinuitas, komprehensif, adil, objektif, kooperatif, dan praktis. Adapun secara khusus, prinsipnya terdiri dari keterpaduan, koherensi, pedagogis, dan akuntabilitas. Dipandang dari jenisnya, evaluasi pembelajaran terdiri dari evaluasi perencanaan, pengembangan, monitoring, dampak, efisiensi, dan program komprehensif. Ditinjau dari objeknya, evaluasi pembelajaran meliputi input, transformasi, dan output. Adapun dari subjeknya ialah pendidik, petugas yang telah dibina, bahkan peserta didik pun bisa mengevaluasi diri sendiri. Dari segi tekniknya terdiri dari tes dan non-tes. Implikasinya, evaluasi pembelajaran Pendidikan Agama Islam di sekolah mesti dilakukan secara kontinuitas, komprehensif, dan terintegrasi. Dengan demikian, pendidik Pendidikan Agama Islam harus mampu mengevaluasi perkembangan peserta didik mencakup aspek aqliyah, qolbiyah, dan amāliyah..
\end{abstract}

Kata Kunci : Evaluasi, Pembelajaran, Pendidikan Agama Islam, Sekolah 
E-ISSN: 2528-2476

\section{PENDAHULUAN}

Pendidikan di suatu negara mesti diperhatikan baik dari segi perencanaan, pelaksanaan, dan evaluasi, karena pendidikan merupakan salah satu bidang yang akan melahirkan sumber daya manusia yang berkualitas. Oleh karena itu, pelaksanaan pendidikan sebagai bagian dalam mencerdaskan kehidupan bangsa mesti mendapat perhatikan penuh dari pemangku kebijakan yang ada di negeri ini, sebagaimana tercantum dalam pasal 31 Undang-Undang Dasar 1945 amandemen ke 4 bahwa setiap warga negara berhak mendapat pendidikan. Raharjo (2012) mencatat bahwa pendidikan di Indonesia diselenggarakan melalui jalur, jenjang, dan jenis pendidikan. Jalur pendidikan adalah wahana yang dilalui peserta didik untuk mengembangkan potensi dirinya dalam suatu proses pendidikan yang sesuai dengan tujuan pendidikan. Terdapat tiga jalur pendidikan yaitu jalur pendidikan formal, nonformal, dan informal. Pendidikan formal adalah jalur pendidikan yang terstruktur dan berjenjang terdiri dari pendidikan dasar, pendidikan menengah, dan pendidikan tinggi. Pendidikan nonformal adalah jalur pendidikan di luar pendidikan formal yang dilaksanakan secara terstruktur dan berjenjang. Pendidikan informal adalah jalur pendidikan keluarga dan lingkungan.

Tujuan utama pendidikan dalam rangka membina manusia dari segi intelektual, emosional, dan spiritual (Naima \& Erniati, 2013). Ditinjau dari tujuannya, output pendidikan harusnya mampu melahirkan sumber daya manusia yang memiliki keunggulan baik segi intelektual, emosional dan spiritual. Pendidikan mesti mampu menjawab tantangan perkembangan ilmu pengetahuan dan teknologi yang disertai arus informasi yang semakin hari semakin pesat perkembangannya. Dengan demikian, pendidikan sebagai proses dalam pengembangan insan akan menghadapi tantangan semakin besar dan komplek di masa depan. Tantangan tersebut menuntut penyelenggaraan pendidikan untuk meningkatkan kualitas dan kuantitas, salah satunya penyelenggaraan pendidikan yang ada di Indonesia. Dalam era globalisasi seperti dewasa ini, pendidikan bukan lagi suatu prestise sosial, melainkan lebih mengacu pada pengembangan diri secara optimal dan pemenuhan kebutuhan tiap individu sesuai dengan pola, tugas-tugas perkembangannya, dan tuntutan dunia kerja serta kehidupan yang akan dimasukinya (Yusuf, 2015:1). Sementara itu, perkembangan ilmu pengetahuan dan teknologi jika tidak dibarengi dengan kualitas pendidikan yang 
memadai akan menyebabkan kualitas sumber daya manusia bangsa Indonesia mengalami krisis dari segala bidang, salah satunya bidang pendidikan (Hidayat, Rizal, \& Fahrudin, 2018a). Oleh karena itu, tuntutan perbaikan kualitas dan kuantitas pendidikan mesti diimbangi dengan kualitas guru yang harus memiliki kompetensi yang diperlukan dalam mengajar. Salah satu kompetensi yang harus dikuasi oleh guru adalah kompetensi pedagogik yang di dalamnya harus menguasai aspek evaluasi pembelajaran. Namun realita di lapangan masih ditemukan beberapa guru yang kesulitan dalam pelaksanaan evaluasi pembelajarannya, salah satunya dalam konteks guru Pendidikan Agama Islam (PAI). Di sisi lain, masih banyak ditemukan guru PAI yang belum bisa membedakan istilah evaluasi, penilaian, pengukuran, dan tes. Hal demikian menyebabkan belum berhasilnya guru PAI dalam membina pengembangan moral peserta didik.

Syafri (2016) mengobservasi bahwa guru PAI kurang berminat dalam melakukan penilaian baik di awal pembelajaran maupun selama proses berlangsungnya pembelajaran. Guru PAI lebih cenderung melakukan penilaian ketika di akhir pembelajaran saja. Padahal dengan melakukan tes di awal pembelajaran akan membantu guru untuk menentukan dari mana pembelajaran dimulai. Apabila melakukan penilaian selama berlangsungnya proses pembelajaran tentunya akan diketahui kemampuan dan kelemahan siswa dalam penguasaan pengetahuan dan keterampilan, sehingga dapat dilakukan perbaikan dan pengayaan Sementara itu, Qowaid \& Setianingsih (2006) meneliti bahwa peran guru PAI sebagai sosok sentral dalam menanamkan nilai-nilai moral belum terasa peranannya secara optimal, padahal karakteristik pendidikan agama yang khas menuntut adanya guru yang berkualitas, guru yang memiliki kompetensi dan kesanggupan yang lebih lengkap dibandingkan dengan guru pada umumnya. Mereka tidak sekedar dituntut memiliki kompetensi pedagogik pada umumnya dan profesional yang unggul, melainkan kompetensi individual, kepribadian, dan keteladanan.

Berdasarkan permasalahan di atas, tentu ada sebab yang mempengaruhi. Hidayat \& Suryana (2018) melaporkan permasalahan yang ada dalam pendidikan tidak terlepas dari krisis multidimensional yang terjadi di negeri ini baik di bidang pendidikan, ekonomi, kesehatan, sosial, budaya, politik, hukum, dan pemerintahan. Hanun (2016) mengobservasi kenyataan sekarang ini, lembaga-lembaga pendidikan belum sepenuhnya 
berhasil dalam pengembangan moral dan pembentukan perilaku peserta didik dalam mengantisipasi masalah-masalah etis dan moral. Kondisi ini mendorong pemerintah untuk segera mengevaluasi ulang materi pembelajaran, sumber daya guru dan dosen dalam memberi pembelajaran, termasuk juga metode pembelajarannya. Di sisi lain, Nurharjadmo \& Negara (2008) mengamati berbagai permasalahan yang muncul dalam sistem pendidikan di Indonesia : Pertama, rendahnya mutu pendidikan. Kedua, belum adanya pemerataan dalam memperoleh akses di bidang pendidikan. Ketiga, tidak adanya efisiensi dalam penyelenggaraan pendidikan. Keempat, belum adanya demokratisasi pendidikan. Peran serta masyarakat dalam dunia pendidikan masih sangat terbatas.

Berdasarkan beberapa penyebab yang menimbulkan masalah pendidikan sebagaimana di uraikan di atas, salah satu penyebab yang menarik untuk disoroti adalah belum optimalnya implementasi evaluasi yang efektif dan efisien. Tayibnapis (2008: 2) mencatat bahwa kesadaran akan evaluasi merupakan salah satu langkah ke arah perbaikan, karena evaluasi dapat memberikan pendekatan yang lebih banyak dalam memberikan informasi kepada pendidikan untuk membantu perbaikan dan pengembangan sistem pendidikan. Oleh karena itu, orang-orang yang berpengaruh dalam bidang pendidikan seperti pakar pendidikan, para pemangku kebijakan, dan yang menyetujui program pendidikan perlu dievaluasi. Berangkat dari hal ini, diperlukan solusi untuk menyelesaikan permasalahan tersebut, jika tidak diselesaikan akan menghambat dalam proses pendidikan. Dari sekian banyak penyebab permasalahan dalam pendidikan, dapat diidentifikasi salah satu penyebabnya yakni guru PAI masih minim dan belum memiliki keahlian yang baik dari sisi evaluasi. Oleh karena itu, sangat penting kiranya untuk diadakan pengkajian mengenai konsep dasar evaluasi dan implikasinya dalam evaluasi pembelajaran PAI di sekolah.

Supriadi (2009) melaporkan PAI merupakan mata pelajaran yang penting untuk diajarkan di setiap jenjang pendidikan. Pelaksanaan proses pembelajaran PAI berorientasi pada pencapaian tujuan. Tujuan PAI sudah tertuang dalam standar kompetensi yaitu menumbuhkan dan meningkatkan keimanan, melalui pemberian dan pemupukan pengetahuan, penghayatan, pengamalan serta pengalaman peserta didik tentang agama Islam, sehingga menjadi manusia muslim yang terus berkembang dalam 
hal keimanan, ketakwaannya kepada Allah Subhānahu Wata'ālā serta berakhlak mulia dalam kehidupan pribadi, masyarakat, berbangsa, dan bernegara, serta untuk dapat melanjutkan pada jenjang pendidikan yang lebih tinggi.

Untuk melihat keberhasilan mata pelajaran PAI diperlukan evaluasi. Dalam evaluasi perlu adanya teknik, dan sasaran untuk menuju keberhasilan dalam proses belajar mengajar dan pendidikan secara keseluruhan. Evaluasi yang baik haruslah didasarkan atas tujuan yang ditetapkan berdasarkan perencanaan sebelumnya dan kemudian benar-benar diusahakan oleh guru untuk peserta didik. Betapapun baiknya evaluasi apabila tidak didasarkan atas tujuan yang telah ditetapkan, tidak akan tercapai sasarannya (Miswanto, 2014). Proses evaluasi harus tepat terhadap tipe tujuan yang biasanya dinyatakan dalam bahasa prilaku. Dikarenakan tidak semua perilaku dapat dinyatakan dengan alat evaluasi yang sama, maka evaluasi menjadi salah satu hal yang sulit dan menantang yang harus disadari oleh para guru (Sukardi, 2011: 1). Berdasarkan uraian di atas, penulis tertarik untuk membahas konsep dasar evaluasi dan implikasinya dalam pembelajaran PAI di sekolah. Pembahasan ini diharapkan mampu menyelesaikan salah satu penyebab permasalahan yang ada dalam dunia pendidikan, salah satunya berkaitan dengan permasalahan evaluasi pembelajaran.

\section{METODOLOGI PENELITIAN}

Pembahasan ini menggunakan pendekatan kualitatif dan metode studi literatur. Teknik pengambilan data dengan cara mengkaji berbagai sumber literatur yang berasal dari berbagai dokumen. Gunawan (2013:175) mencatat bahwa sifat utama data dokumen ini tak terbatas pada ruang dan waktu sehingga memberi peluang kepada peneliti untuk mengetahui hal-hal yang pernah terjadi di waktu silam. Secara detail bahan dokumenter terbagi beberapa macam, yaitu otobiografi, surat-surat pribadi, buku, catatan harian, memorial kliping, dokumen pemerintah atau swasta, data di server, flasdisk, dan website. Penulis mengumpulkan sumber literatur dalam bentuk dokumen, baik dari buku, jurnal, hasil seminar, dan diskusi dengan ahli yang relevan dengan penelitian. Setelah data terkumpul maka dilakukan analisis data. Pembahasan yang dilakukan terhadap informasi yang berasal dari dokumentasi baik dalam bentuk tulisan, rekaman, dan gambar, biasa dikenal dengan penelitian analisis isi (Arikunto, 2013: 24). 
Penulis menggunakan teknik analisis isi, yakni dengan cara menginterpretasi data, menambahkan penjelasan, dan penarikan kesimpulan.

\section{HASIL PENELITIAN DAN PEMBAHASAN Konsep Dasar Evaluasi}

Secara harfiah, evaluasi berasal dari bahasa inggris evaluation, dalam bahasa Arab al-Taqdìr, dalam bahasa Indonesia berarti penilaian. Akar katanya adalah value, dalam bahasa Arab al-Qìmaћ, dalam bahasa Indonesia berarti nilai. Pengukuran dalam bahasa Inggris dikenal dengan measurement dan dalam bahasa Arab adalah muqayasaћ, dapat diartikan sebagai kegiatan yang dilakukan untuk mengukur sesuatu. Mengukur pada hakikatnya membandingkan sesuatu dengan atau atas dasar ukuran tertentu. Adapun penilaian mengandung arti mengambil keputusan terhadap sesuatu dengan mendasarkan diri atau berpegang pada ukuran baik atau buruk, sehat atau sakit, dan sebagainya. Adapun evaluasi adalah mencakup dua kegiatan yang dikemukakan yakni pengukuran dan penilaian (Sudijono, 2008: 1-5).

Satu hal yang mencirikan evaluasi bahwa proses ini diakhiri dengan pengambilan keputusan. Keputusan ini berkenaan dengan keberhargaan dan manfaat dari evaluan (Mahmudi, 2011). Evaluasi lebih luas lingkupnya daripada penilaian, sedangkan penilaian lebih terfokus pada aspek tertentu saja yang merupakan bagian dari ruang lingkup tersebut. Jika hal yang dinilai adalah sistem pembelajaran, maka ruang lingkupnya adalah semua komponen pembelajaran dan istilah yang tepat untuk menilai sistem pembelajaran adalah evaluasi bukan penilaian. Jika hal yang ingin dinilai satu atau beberapa bagian/komponen pembelajaran, misalnya hasil belajar, istilah yang tepat digunakan adalah penilaian bukan evaluasi. Di sisi lain, ada juga istilah pengukuran. Jika evaluasi dan penilaian bersifat kualitatif, maka pengukuran bersifat kuantitatif (skor/angka) yang diperoleh dengan menggunakan suatu alat ukur (Arifin, 2012: 2).

Berdasarkan uraian di atas dapat dipahami bahwa evaluasi terdiri dari pengukuran dan penilaian. Satu hal yang mencirikan evaluasi, proses ini diakhiri dengan pengambilan keputusan. Keputusan ini berkenaan dengan keberhargaan dan manfaat dari evaluan. Evaluasi cakupannya lebih luas dari penilaian, adapun penilaian yang dilihat hanya ruang lingkup tertentu saja. Jika yang dinilai merupakan sistem 
pembelajaran secara keseluruhan, maka istilah yang tepat untuk menilai sistem pembelajaran adalah evaluasi. Adapun jika yang dinilai hanya satu atau beberapa komponen pembelajaran, misalnya hasil belajar, istilah yang tepat digunakan adalah penilaian. Penilaian bersifat kualitatif, dan pengukuran bersifat kuantitatif yang diperoleh menggunakan suatu alat ukur. Adapun evaluasi bersifat kualitatif dan kuantitatif. Evaluasi mempunyai kedudukan yang sangat penting dan strategis karena evaluasi merupakan suatu bagian yang tak terpisahkan dari pembelajaran itu sendiri. Hampir semua ahli prosedur sistem intruksional menempatkan evaluasi sebagai langkah-langkahnya (Arifin, 2012), (Putra, 2013: 76). Jika suatu pembelajaran tidak ada evaluasi dalam langkah-langkahnya, maka pembelajaran demikian tidak akan diketahui keberhasilannya. Oleh karena itu, evaluasi memiliki kedudukan yang sangat penting.

Tujuan Evaluasi ada dua Tujuan Umum dan tujun khusus, Tujuan Umum: Pertama Untuk menghimpun bahan-bahan keterangan yang akan dijadikan sebagai bukti mengenai taraf perkembangan yang dialami oleh peserta didik, setelah mereka mengikuti proses pembelajaran dalam jangka waktu tertentu. Kedua Untuk mengetahui tingkat efektivitas dari metode-metode pengajaran yang telah dipergunakan dalam proses pembelajaran selama jangka waktu tertentu (Sudijono, 2008: 16). Sedangkan Tujuan Khusus Pertama Untuk merangsang kegiatan peserta didik dalam menempuh program pendidikan. Tanpa adanya evaluasi maka tidak mungkin timbul rangsangan pada diri peserta didik untuk memperbaiki dan meningkatkan prestasinya masingmasing. Kedua Untuk menemukan faktor-faktor penyebab keberhasilan dan ketidakberhasilan peserta didik dalam mengikuti program pendidikan, sehingga dapat dicari dan ditemukan cara-cara perbaikan (Sudijono, 2008: 17).

Adapun Arifin (2012: 14) mencatat bahwa tujuan evaluasi dalam pembelajaran adalah untuk mengetahui keefektifan dan efisiensi sistem pembelajaran, baik yang menyangkut tentang tujuan, materi, metode, media, sumber belajar, lingkungan maupun sistem penilaian itu sendiri. Tujuan khusus evaluasi pembelajaran disesuaikan dengan jenis evaluasi pembelajaran itu sendiri seperti evaluasi perencanaan dan pengembangan, evaluasi monitoring, evaluasi dampak, evaluasi efisiensi - ekonomis, dan evaluasi program komprehensif. Berdasarkan uraian di atas dapat dipahami, secara umum evaluasi bertujuan untuk mengetahui perkembangan peserta didik selama mengikuti 
pembelajaran dan dalam rangka mengetahui efektivitas dan efisiensi proses pembelajaran. Adapun secara khusus untuk merangsang peserta didik supaya memperbaiki dan meningkatkan prestasinya serta menemukan faktor-faktor penyebab keberhasilan dan ketidakberhasilan peserta didik dalam mengikuti program pendidikan, sehingga akan ditemukan cara mengatasinya.

Fungsi Evaluasi Sudijono (2008: 8-15) melaporkan secara umum, evaluasi sebagai suatu tindakan proses setidak-tidaknya memiliki tiga macam fungsi pokok, yaitu : Pertama, mengukur kemajuan. Kedua, menunjang penyusunan rencana. Ketiga, memperbaiki atau melakukan penyempurnaan kembali. Adapun secara khusus, fungsi evaluasi dalam pendidikan dapat ditilik dari tiga segi, yaitu : Pertama, segi psikologis bagi peserta didik untuk mengenal kapasitas dan status dirinya. Adapun bagi pendidikan untuk kepastian hasil usahanya. Kedua, segi didaktik bagi peserta didik untuk dorongan perbaikan dan peningkatan prestasi. Adapun bagi pendidikan berfungsi sebagai diagnostik, penempatan, selektif, bimbingan, dan instruksional. Ketiga, segi administratif untuk memberikan laporan, memberikan data, dan memberikan gambaran.

Sedangkan Arifin (2012:19-20) mencatat bahwa fungsi evaluasi pembelajaran adalah : Pertama, untuk perbaikan dan pengembangan sistem pembelajaran. Dengan demikian perbaikan dan pengembangan pembelajaran bukan hanya terhadap proses dan hasil belajar melainkan harus diarahkan pada semua komponen pembelajaran tersebut. Kedua, untuk akreditasi. Dalam UU No. 20 tahun 2003 Bab 1 Pasal 1 Ayat 22 dijelaskan "akreditasi adalah kegiatan penilaian kelayakan program dalam satuan pendidikan berdasarkan kriteria yang telah ditetapkan". Salah satu komponen akreditasi adalah pembelajaran. Artinya fungsi akreditasi dapat dilaksanakan jika hasil evaluasi pembelajaran digunakan sebagai dasar akreditasi lembaga pendidikan. Berdasarkan uraian di atas dapat dipahami, secara umum fungsi evaluasi terdiri dari mengukur kemajuan, menunjang penyusunan rencana, dan memperbaiki penyempurnaan kembali. Adapun secara khusus, evaluasi berfungsi dari segi psikologis untuk mengenal kapasitas dan status diri peserta didik. Segi didaktik untuk perbaikan dan peningkatan prestasi. Bagi pendidikan berfungsi sebagai diagnostik, penempatan, selektif, bimbingan, dan instruksional. Segi administratif untuk memberikan laporan, data, dan gambaran. Contohnya pengembangan sistem pembelajaran dan akreditasi. 
Kegunaan yang dapat dipetik dari kegiatan evaluasi dalam bidang pendidikan adalah : (i). Terbukanya kemungkinan bagi evaluator guna memperoleh informasi tentang hasil-hasil yang telah dicapai dalam rangka pelaksanaan program pendidikan. (ii). Terbukanya kemungkinan untuk diketahui relevansinya antara program pendidikan yang telah dirumuskan, dengan tujuan yang hendak dicapai. (iii). Terbukanya kemungkinan untuk dapat dilakukannnya usaha perbaikan, penyesuaian, dan penyempurnaan program pendidikan yang dipandang lebih berdaya guna dan berhasil guna, sehingga tujuan yang dicita-citakan, akan dapat dicapai dengan hasil yang sebaikbaiknya (Sudijono, 2008: 17). Berbagai pihak seperti guru, siswa, sekolah, masyarakat dan pemerintah memperoleh manfaat dari kegiatan evalauasi pendidikan (Purwanto, 2011:17). Bentuk nyatanya dalam akreditasi dan sertifikasi. Pengukuran kualitas sekolah harus dirancang dalam bentuk instrumen evaluasi seperti akreditasi sekolah melalui instrumen evaluasi diri sekolah, sertifikasi melalui instrumen evaluasi kelayakan untuk guru dalam bentuk portofolio, nasional penambangan dalam bentuk instrumen evaluasi untuk ujian nasional (Wijaya \& Sumarno, 2017). Berdasarkan uraian di atas dapat dipahami bahwa evaluasi memiliki berbagai macam kegunaan, diantaranya kegunaan bagi evaluator untuk mengetahui hasil yang telah dicapai, untuk mengetahui relevansi antara program yang telah dirumuskan dengan tujuan yang hendak dicapai, terbukanya untuk dilakukan perbaikan, penyesuaian dan penyempurnaan program. Beberapa pihak seperti guru, siswa, sekolah, masyarakat, dan pemerintah pun memperoleh manfaat atas kegiatan evaluasi.

Sudijono (2008: 29) mencatat secara umum ruang lingkup evaluasi pendidikan di sekolah mencakup tiga komponen utama, yaitu : Pertama, evaluasi mengenai program pendidikan. Kedua, evaluasi mengenai proses pelaksanaan pendidikan. Ketiga, evaluasi mengenai hasil pendidikan. Adapun Arifin (2012: 30) melaporkan secara keseluruhan, ruang lingkup evaluasi pembelajaran meliputi : Pertama, domain hasil belajar antara lain domain kognitif, afektif, dan psikomotorik. Kedua, sistem pembelajaran antara lain program pembelajaran, proses pelaksanaan pembelajaran, dan hasil belajar. Ketiga, proses dan hasil belajar antara lain sikap, pengetahuan, pemahaman, kecerdasan, perkembangan jasmani, dan keterampilan. Keempat, penilaian berbasis kelas antara lain kompetensi dasar mata pelajaran, kompetensi rumpun 
pelajaran, kompetensi lintas kurikulum, kompetensi tamatan, dan keterampilan hidup. Berdasarkan uraian di atas dapat dipahami bahwa ruang lingkup evaluasi pendidikan mencakup program pendidikan, pelaksanaan pendidikan, dan hasil pendidikan. Adapun dari segi pembelajaran, ruang lingkup evaluasi mencakup domain kognitif, afektif, dan psikomotorik. Kemudian sistem pembelajaran, proses dan hasil belajar serta penilaian berbasis kelas.

Ada satu prinsip umum dan penting dalam kegiatan evaluasi, yaitu adanya triangulasi atau hubungan erat tiga komponen, yaitu antara : Pertama, tujuan pembelajaran. Kedua, kegiatan pembelajaran. Ketiga, evaluasi (Arikunto, 2003: 24). Untuk mencapai hasil evaluasi yang lebih baik, proses evaluasi harus beritik tolak dari prinsip-prinsip umum sebagai berikut : kontinuitas, komprehensif, adil, objektif, kooperatif, dan praktis (Arifin, 2012: 31). Adapun Daryanto (2012: 19-21) mencatat bahwa prinsip-prinsip evaluasi adalah sebagai berikut : Pertama, keterpaduan, evaluasi merupakan komponen integral dalam program pengajaran di samping tunjuan intruksional dan materi serta metode pengajaran. Kedua, keterlibatan siswa, evaluasi bagi siswa merupakan kebutuhan, bukan sesuatu yang ingin dihindari. Ketiga, koherensi, dimaksudkan evaluasi harus berkaitan dengan materi pembelajaran yang sudah disajikan dan sesuai dengan ranah kemampuan yang hendak diukur. Keempat, pedagogis, evaluasi perlu diterapkan sebagai upaya perbaikan sikap dan tingkah laku ditinjau dari segi pedagogis. Kelima, akuntabilitas, sejauh mana keberhasilan program pembelajaran perlu disampaikan kepada pihak-pihak yang berkepentingan dengan pendidikan sebagai laporan pertanggungjawaban. Berdasarkan uraian di atas dapat dipahami bahwa prinsip-prinsip evaluasi terdiri dari triangulasi antara tiga komponen yaitu tujuan, proses, dan evaluasi. Prinsip umumnya yaitu kontinuitas, komprehensif, adil, objektif, kooperatif, dan praktis. Serta prinsip terintegrasi, keterlibatan siswa, koherensi, pedagogis, dan akuntabilitas.

Klasifikasi evaluasi pendidikan terdiri dari tiga kategori, yaitu : Pertama, klasifikasi evaluasi pendidikan yang didasarkan pada fungsi evaluasi dalam proses pendidikan, diantaranya dalam rangka memenuhi kebutuhan psikologis, didaktik, dan administratif: Kedua, klasifikasi evaluasi pendidikan yang didasarkan pada pemanfaatan informasi yang bersumber dari kegiatan evaluasi itu sendiri: (1) Berdasarkan banyaknya 
orang yang terlihat dalam pengambilan keputusan pendidikan seperti pengambilan keputusan secara individu, dan institusi. (2) Berdasarkan macamnya keputusan pendidikan diantaranya dalam rangka mengambil keputusan bersifat didaktif, bimbingan, penyuluhan, administratif, dan kegiatan riset: Ketiga, klasifikasi evaluasi pendidikan yang dilatarbelakangi oleh pernyataan: Dimana atau ada bagian manakah evaluasi itu dilaksanakan dalam rangka proses pendidikan diantaranya evaluasi formatif dan sumatif (Sudijono, 2008).

Adapun Arifin (2012: 33) mengemukakan sebagai suatu program, evaluasi pembelajaran dibagi menjadi lima jenis, yaitu : Pertama Evaluasi perencanaan dan pengembangan; Hasil evaluasi ini sangat diperlukan untuk mendesain program pembelajaran. Sasaran utamanya adalah memberikan bantuan tahap awal dalam penyusunan program pembelajaran. Persoalan yang disoroti menyangkut tentang kelayakan dan kebutuhan. Kedua Evaluasi monitoring: Evaluasi ini dimaksudkan untuk memeriksa apakah program pembelajaran mencapai sasaran secara efektif dan apakah program pembelajaran terlaksana sebagaimana mestinya. Ketiga Evaluasi dampak: Evaluasi ini dimaksudkan untuk mengetahui dampak yang ditimbulkan oleh suatu program pembelajaran. Dampak ini dapat diukur berdasarkan kriteria keberhasilan sebagai indikator ketercapaian tujuan program pembelajaran. Keempat Evaluasi efisiensi - ekonomis. : Evaluasi ini dimaksudkan untuk menilai tingkat efisiensi pelaksanaan program pembelajaran. Untuk itu, diperlukan perbandingan antara jumlah biaya, tenaga, dan waktu yang diperlukan dalam suatu program pembelajaran dengan program lainnya yang memiliki tujuan yang sama. Kelima Evaluasi program komprehensif: Evaluasi ini dimaksudkan untuk menilai program pembelajaran secara menyeluruh, seperti perencanaan program, pelaksanaan program, monitoring pelaksanaan, dampak program, tingkat keefektifan, dan efisiensi. Dalam model evaluasi dikenal dengan educational system evaluation model.

Berdasarkan uraian di atas dapat dipahami bahwa evaluasi pendidikan terdiri dari tiga kategori. Pertama, didasarkan pada fungsi evaluasi dalam proses pendidikan mencakup kebutuhan psikologi, didaktik, dan asministratif. Kedua, didasarkan pada pemanfaatan informasi yang bersumber dari kegiatan evaluasi. Ketiga, evaluasi formatif dan sumatif. Adapun evaluasi pembelajaran terdiri dari 5, diantaranya : Pertama, 
evaluasi perencanaan dan pengembangan. Kedua, evaluasi monitoring. Ketiga, evaluasi dampak. Keempat, evaluasi efisiensi ekonomis. Kelima, evaluasi program komprehensif.

Ditinjau dari segi input, objek evaluasi pendidikan terdiri dari aspek kemampuan, kepribadian, dan sikap. Dari segi subjek evaluasi pendidikan, jika sasarannya adalah prestasi belajar, maka subjek evaluasinya guru dan dosen yang mengampu mata pelajaran tertentu. Jika sasaran evaluasinya sikap peserta didik, maka subjek evaluasinya adalah guru atau petugas yang telah memperoleh pelatihan mengenai cara-cara menilai sikap seseorang. Apabila sasaran evaluasinya kepribadian, maka menggunakan tes instrument yang bersifat baku, maka subjek evaluasinya adalah psikolig atau yang ahli di bidangnya (Sudijono, 2008: 25-29). Sasaran evaluasi untuk unsur-unsurnya meliputi : Pertama, input yakni aspek yang bersifat rohani setidaknya mencakup 4 hal yaitu kemampuan, kepribadian, sikap, dan intelegensi. Kedua, transformasi, yakni kurikulum/materi, metode, cara penilaian, sarana pendidikan/media, sistem administrasi, guru dan personal lainnya. Ketiga, output yakni output yakni evaluasi terhadap lulusan suatu sekolah dilakukan untuk mengetahui seberapa jauh tingkat pencapaian/prestasi belajar mereka selama mengikuti program. Alat yang digunakan untuk mengukur pencapaian ini disebut tes pencapaian (Arikunto, 2013: 2022). Berdasarkan uraian di atas dapat dipahami, objek evaluasi untuk unsur-unsurnya meliputi input, transformasi, dan output. Ditinjau dari segi input adalah peserta didik. Dari segi transformasi terdiri dari kurikulum, metode, cara penilaian, sarana prasarana, sistem administrasi, guru, dan personal lainnya. Adapun dari segi output merupakan lulusan suatu sekolah. Subjek yang melakukan evaluasi ialah guru, petugas yang telah dibina, dan psikolog.

Secara garis besar, teknik evaluasi dapat digolongkan menjadi 2 macam, yaitu : teknik tes dan teknik non tes. Teknik tes merupakan pengumpul informasi bersifat lebih resmi karena penuh dengan batasan-batasan. Jika dikaitkan evaluasi suatu kelas di sekolah, maka tes mempunyai fungsi ganda yaitu untuk mengukur siswa dan keberhasilan program pembelajaran. Ditinjau dari segi kegunaan untuk mengukur siswa maka dibedakan atas 3 macam tes, yaitu : tes diagnostik, tes formatif, dan tes sumatif. Adapun teknik non tes terdiri dari skala bertingkat (rating scale), kuisioner 
(questionaire), daftar cocok (check-list), wawancara (interview), pengamatan (observation), dan riwayat hidup (Daryanto, 2012: 28-36). Berdasarkan uraian di atas dapat dipahami bahwa teknik evaluasi terdiri dari teknik tes dan non-tes. Teknik tes berupa alat pengumpul informasi yang bersifat resmi dan memiliki batasan. Maka dibedakan atas 3 macam tes, yaitu tes diagnostik, tes formatif, dan tes sumatif. Adapun teknik non tes terdiri dari skala bertingkat, kuisioner, daftar cocok, wawancara, pengamatan, riwayat hidup.

Berdasarkan uraian di atas, untuk memudahkan dalam memahami konsep dasar evaluasi, dapat dibuatkan bagan sebagai berikut :

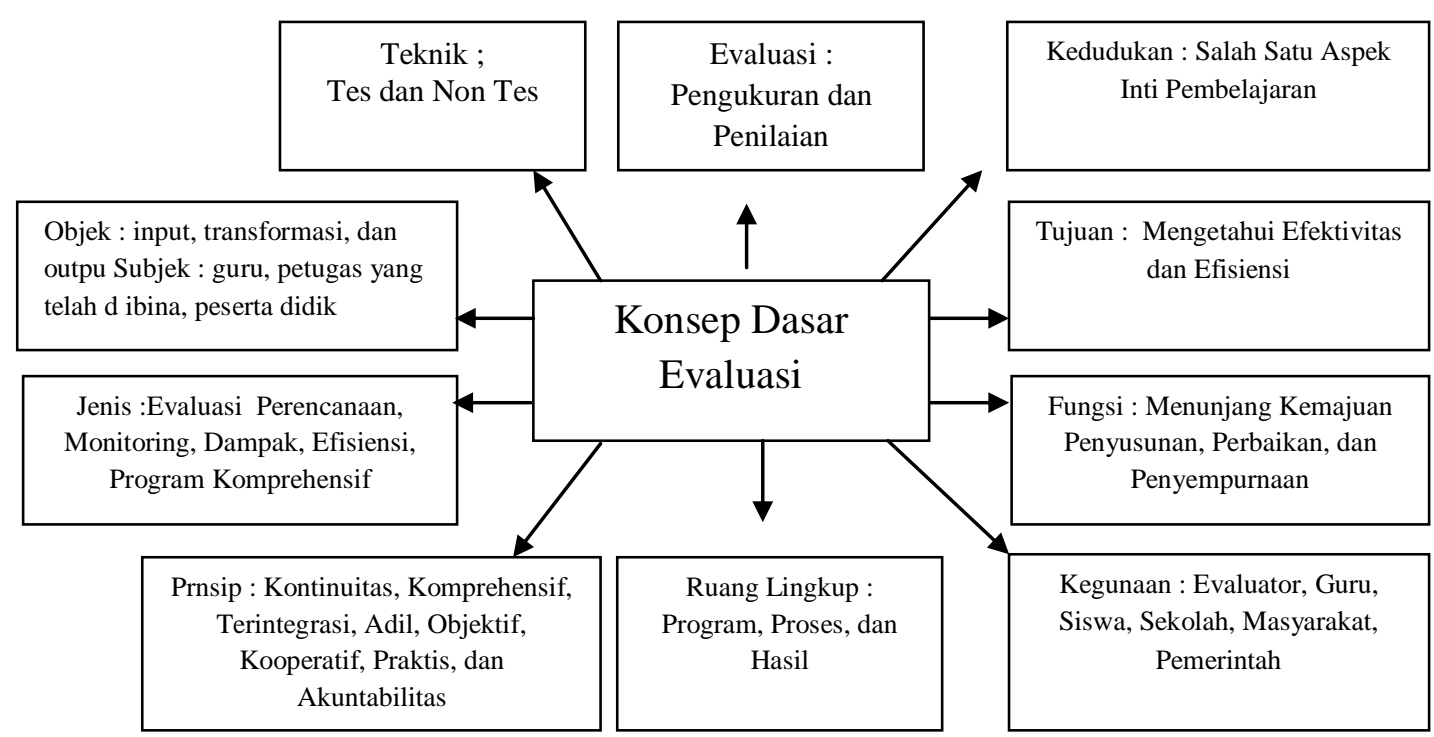

Bagan 1 Konsep Dasar Evaluasi

\section{Implikasinya Dalam Evaluasi Pembelajaran Pendidikan Agama Islam di Sekolah}

Pembelajaran merupakan salah satu aspek inti dalam pendidikan, pembelajaran didalamnya mencakup aspek perencanaan, pelaksanaan, dan evaluasi. Pembelajaran yang baik dapat diketahui tatkala evaluasi telah dilakukan, adapun evaluasi dilakukan untuk mengetahui sejauh mana ketercapaian tujuan pembelajaran yang telah direncanakan. Dalam pendidikan Islam, evaluasi memiliki kedudukan yang sangat penting untuk mengukur dan menilai sejauh mana keberhasilan pendidikan itu dilaksanakan.

Sebelum mengevaluasi pendidikan Islam, terlebih dahulu harus mengetahui hakikat pendidikan Islam itu sendiri, supaya dalam proses evaluasi selaras ranah yang mesti dievaluasinya. Ismail (2013) mencatat pendidikan Islam sebagai sebuah proses 
pengalihan pengetahuan, pemahaman, nilai-nilai dan pengamalan agama Islam secara terencana, sistemik, dan berkelanjutan. Dengan kata lain, pendidikan Islam merupakan upaya untuk menumbuh-kembangkan potensi fitrah anak didik yang di bawa sejak lahir menjadi sebuah kemampuan dan kekuatan yang dapat melahirkan kompetensi yang profesional. Fitrah di sini sebagai suatu kecenderungan (potensi) untuk mengetahui, memahami dan mengamalkan ajaran Islam selaku hamba Allah Subhanahu Wa Ta'àlā di muka bumi.

Oleh karena itu, untuk mengetahui ketercapaian sebuah proses pendidikan Islam, perlu diadakan evaluasi yang komprehensif dan terintegrasi mencakup seluruh aspek yang mesti dievaluasi. Nuryamin (2011) mengamati bahwa hakekat evaluasi pendidikan Islam adalah konsep berpikir tentang penilaian dalam proses belajar mengajar yang mempunyai tujuan dan fungsi untuk mengetahui tingkat keberhasilan dalam mencapai tujuan pendidikan yang dicita-citakan, yakni dalam membina kepribadian Islami.

Pendidikan Islam merupakan konsep pendidikan yang terintegrasi dan komprehensif. Oleh karena itu, evaluasi yang dilakukannya pun harus terintegrasi, komprehensif, dan sistemik. Dudin (2007) melaporkan untuk menjamin pengembangan mutu penyelenggaraan pendidikan, perlu diadakan evaluasi yang bersifat sistemik mencakup : Pertama, aspek input meliputi standar isi, standar pendidik, standar tenaga kependidikan, standar sarana dan prasarana. Kedua, aspek proses meliputi standar proses, standar pengelolaan, dan standar penilaian pendidikan. Ketiga, aspek output, meliputi standar kompetensi lulusan, dari segi pengetahuan, keterampilan, dan sikap.

PAI merupakan mata pelajaran yang memiliki ciri khas tersendiri dan memiliki perbedaan dengan mata pelajaran lainnya. Ciri khas yang ada dalam mata pelajaran PAI yakni selalu terikat dengan nilai-nilai ilāhiyah, dan itu merupakan nilai yang inti. Oleh karena itu, mesti dilakukan evaluasi yang terintegrasi dan komprehensif mencakup seluruh ranah yang dituju, baik aspek aqliyah, qolbiyah, dan amāliyah.

Hidayat \& Syafe'i (2018) mencatat bahwa aqliyah berbeda dengan kognitif, karena aqliyah berkaitan dengan perintah dan larangan Allah Subhānahu Wa Ta'ālâ. Aspek qolbiyah berbeda dengan afektif, sikap yang dilakukan berdasarkan perintah dan larangan Allah Subhānahu Wa Ta'ālâ. Begitupun dengan aspek amāliyah berbeda dengan psikomotorik, keterampilan yang ada bukan hanya sekedar keterampilan semata, 
namun dalam pandangan PAI mesti membedakan, bahwa keterampilan yang ada juga mesti berdasarkan perintah dan larangan Allah Subhānahu Wa Ta'ālâ. Sehingga antara aqliyah, qolbiyah dan amāliyah selalu berkaitan dengan nilai-nilai ilāhiyah.

Sementara itu, evaluasi memiliki kedudukan yang sangat penting untuk mengetahui ketercapaian tujuan pembelajaran PAI. Evaluasi dilakukan bukan hanya menggugurkan kewajiban semata, tetapi ada nilai lebih dari itu, yakni berkaitan dengan hisab. Jika peserta didik sudah memahami tentang pengukuran, penilaian, dan evaluasi yang mesti dilakukan juga oleh dirinya, implikasinya akan memperlancar dan mempengaruhi proses pembelajaran. Ditinjau dari segi tujuannya, mata pelajaran PAI memiliki tujuan yang utuh dalam memahami ilmu pengetahuan, mencakup ranah aqliyah, qolbiyah dan amāliyah. Oleh karena itu, evaluasi yang dilakukan pun harus mencakup semua ranah tersebut. sementara itu, tujuan evaluasi pembelajaran PAI ditujukan untuk mengetahui perkembangan peserta didik selama mengikuti pembelajaran supaya bisa diketahui efektivitas dan efisiennya. Jika ditemukan proses pembelajaran yang tidak sesuai dengan perencanaan, disanalah peran pendidik PAI untuk memperbaiki dan mengatasi masalah yang ditemukan.

Dari segi fungsi, evaluasi berfungsi untuk mengetahui dan mengenal kapasitas pendidik dan pesera didik. Perbaikan prestasi peserta didik, bukan hanya dari segi pengetahuan, tetapi mesti dilihat juga dari segi kepribadian dan keterampilan. Adapun bagi institusi pendidikan, evaluasi berfungsi sebagai diagnostik, supaya diketahui bahwa untuk menanamkan keimanan, ketakwaan, dan akhlak mulia tidak cukup hanya mengandalkan mata pelajaran PAI, tetapi mesti terintegrasi antara seluruh komponen pendidikan yang ada di sekolah. Fungsi evaluasi bagi pembelajaran PAI sebagai bahan untuk menunjang penyusunan perencanaan pembelajaran, sehingga ditemukan kekurangannya kemudian bisa diperbaiki dan disempurnakan, sebagaimana tujuan pembelajaran PAI yang seharunya. Evaluasi mesti mengetahui sejauh mana kemajuan pembelajaran PAI selama ini, baik dilihat dari segi aqliyah, qolbiyah, dan amāliyah. Jangan sampai setiap pembelajaran dan evaluasi yang dilakukan hanya memenuhi formalitas tuntutan pekerjaan saja, dan kering dari nilai-nilai ilāhiyah. Tetapi, evaluasi yang dilakukan mesti memberikan kontribusi dalam melakukan perubahan pembelajaran. 
Evaluasi memiliki kegunaan untuk mengetahui hasil pembelajaran PAI yang telah dicapai, untuk melihat keberhasilan tersebut mesti dikembalikan kepada tujuan pembelajaran yang telah dirumuskan. Hasil pembelajaran mesti relevan dengan program tujuan yang hendak dicapai, jika ditemukan ada ketidakrelevanan, maka evaluasi berguna dalam melakukan perbaikan baik dari segi perencanaan, pelaksanaan, dan hasil belajar. Setelah dilakukan perbaikan berkali-kali, kemudian dilakukan penyesuaian dan penyempurnaan program pembelajaran PAI, maka akan didapatkan rancangan pembelajaran yang lebih baik dari sebelumnya. Ruang lingkup evaluasi pembelajaran PAI mencakup aspek perencanaan, pelaksanaan, dan hasil. Oleh karena itu, cakupan ruang lingkup evaluasi pembelajaran PAI mesti komprehensif dan terintegrasi antara langkah-langkah pembelajarannya. Evaluasi pembelajaran PAI tidak bisa hanya ditentukan dari hasilnya saja, tetapi harus dilihat dari mulai awal hingga akhir, sehingga akan ditemukan hasil yang lebih komprehensif. Domain yang dituju harus mencakup ranah aqliyah, qolbiyah, dan amāliyah.

Prinsip evaluasi mesti mencakup tujuan, proses, dan hasil pembelajaran PAI. Evaluasi pembelajaran PAI mesti dilakukan secara kontinutas, tidak cukup hanya dilakukan satu kali bahkan di akhir semester saja. Tetapi harus dilakukan terus menerus, supaya diketahui perkembangan peserta didik setelah mengikuti pembelajaran. Evaluasi juga mesti komprehensif mencakup ranah aqliyah, qolbiyah, dan amāliyah. Jangan sampai keberhasilan pembelajaran PAI hanya dilihat dari aspek aqliyah saja. Selain itu, pendidik PAI mesti memegang prinsip yang lainnya, yaitu adil, kooperatif, objektif, dan praktis. Jangan sampai pendidik PAI memberikan evaluasi tidak berdasarkan prinsip yang telah disebutkan, apalagi mengevaluasi karena kedekatannya dengan peserta didik, itu bisa menimbulkan kecemberuan sosial dan menyebabkan wibawa pendidik PAI kurang baik di hadapan peserta didik.

Ditinjau dari segi jenisnya, evaluasi pembelajaran PAI mesti mencakup evaluasi perencanaan, evaluasi pengembangan, evaluasi monitoring, evaluasi efisiensi, dan evaluasi program komprehensif. Perencanaan yang telah dibuat mesti dievaluasi, jika ditemukan beberapa yang tidak selaras berdasarkan pengalaman di lapangan, maka lakukan pengembangan. Dengan begitu, perencanaan pembelajaran PAI akan terus berkembang, tidak menggunakan yang itu-itu saja setiap tahunnya. Kemudian 
monitoring yang dilakukan pendidik PAI mesti dievaluasi juga, untuk mengetahui efektivitasnya. Sementara itu, dampak dari pembelajaran PAI mesti dievaluasi untuk mengetahui sejauh mana pembelajaran PAI bisa memberikan perubahan terhadap peserta didik. Kemudian, aspek efisiensi dan ekonomis dilakukan evaluasi supaya diketahui sejauh mana efisiensi pembelajaran PAI di lapangan. Setelah jenis evaluasi dilakukan semua, maka akan ditemukan evaluasi pembelajaran yang komprehensif.

Ditinjau dari segi objek dan subjek evaluasi, objek yang mesti dievaluasi mesti mencakup semua ranah yang mesti ada dalam pembelajaran PAI, yakni ranah aqliyah, qolbiyah, dan amāliyah. Adapun subjek yang melaksanakan evaluasi yang pertama tentunya pendidik PAI, tetapi pendidik PAI bisa juga berkolaborasi dengan petugas yang telah dibina (psikolog), dan guru mata pelajaran lain. Selain itu, pendidik PAI bisa juga meminta informasi dari peserta didik lainnya, supaya didapatkan data yang lebih komprehensif lagi, karena sesama peserta didik biasanya saling mengetahui antara satu dengan yang lainnya. Pendidik juga mesti menanamkan nilai-nilai kesadaran bagi peserta didik untuk melakukan evaluasi diri. Ini penting dilakukan sebagaimana diajarkan sendiri oleh Allah Subhanahu Wa Ta'ālā sebagaimana tercantum melalui firman-Nya :

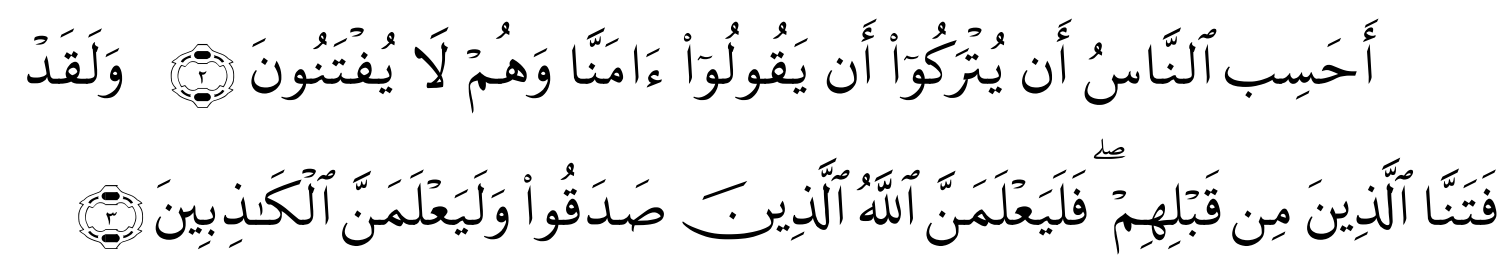

Apakah manusia itu mengira bahwa mereka dibiarkan (saja) mengatakan : "Kami telah beriman", sedang mereka tidak diuji lagi ? dan sesungguhnya Kami telah menguji orang-orang yang sebelum mereka. Maka sesungguhnya Allah mengetahui orang-orang yang benar dan sesungguhnya DIa mengetahui orang-orang yang dusta". (QS. Al-Ankabut [29] : 2-3) (Alquran in Word versi 64 - 3.0 dalam MS Word dan divalidasi oleh peneliti dengan edisi cetak Alquran dan Terjemahnya. Penerjemah: Tim Depag RI, Bandung: CV. Diponegoro, 2015).

Berdasarkan ayat di atas, seorang pendidik mesti mampu menanamkan nilainilai kesadaran kepada peserta didik untuk mengevaluasi dirinya sendiri. Dorongan evaluasi yang dilakukan peserta didik mesti dorongan untuk menghisab diri sendiri, dan itu akan mendorong keberhasilan sebuah pendidikan. 
Ditinjau dari segi teknik, teknik evaluasi pembelajaran PAi terdiri dari teknik tes dan non tes. Teknik tes bisa dilakukan untuk mengetahui pemahaman peserta didik dalam memahami pembelajaran yang telah dilakukan. Waktunya bisa setiap pertemuan, tengah semester, atau pun akhir semester. Bentuknya bisa dalam bentuk tes tulisan, tes lisan, dan tes praktek. Namun yang harus menjadi catatan, teknik tes bukanlah satusatunya untuk melihat keberhasilan pembelajaran, tetapi ada aspek lain yang justru merupakan aspek inti untuk dilakukan evaluasi, yakni berkaitan dengan aspek amāliyah. Dengan demikian, mesti dilakukan evaluasi dengan teknik non tes.

Pendidik PAI mesti terampil dalam melakukan evaluasi teknik non tes ini, karena dari aspek ini merupakan inti dalam pembelajaran PAI, yakni berkaitan dengan pengamalan ajaran agama Islam dalam kehidupan sehari-hari. Pendidikan Islam lebih menekankan proses bukan hasilnya, karena yang wajib itu proses mencari ilmunya, bukan mendapatkan ilmu. Adapun yang memberikan ilmu itu adalah Allah Subhanahu Wa Ta'ālā. Oleh karena itu, pendidik mesti mengevaluasi kesungguhan belajar peserta didik, artinya pembelajaran PAI lebih banyak mengukur, menilai, dan mengevaluasi proses pembelajarannya. Oleh karena itu, pendidik harus melihat perkembangan aqliyah, qolbiyah, dan amāliyah peserta didik. Teknik yang bisa dilakukan bisa dengan observasi, wawancara, kuisioner, bahkan dengan evaluasi yang tidak diketahui oleh peserta didik.

Jika evaluasi PAI bisa dilakukan dengan efektif dan efisien, proses dalam membina kepribadian bisa terwujud. PAI mesti menjadi ujung tombak dalam menanamkan nilai-nilai keimanan, ketakwaan, dan akhlak mulia kepada peserta didik. Ramadhan (2017) mencatat PAI memiliki peranan sentra dalam internalisasi nilai-nilai agama, karena PAI merupakan gerbang utama dalam internalisasi nilai-nilai agama Islam kepada generasi muslim. Selanjutnya, bila internalisasi nilai itu baik maka baiklah generasi muslim, begitu juga sebaliknya. Syahrul (2007) mengamati tujuan pedagogis dari sistem evaluasi terhadap perbuatan manusia diantaranya : Pertama, untuk menguji daya kemampuan manusia yang beriman. Kedua, untuk mengetahui sampai di mana hasil pendidikan wahyu yang telah diterapkan Rasul Allah Sallā Allah 'Alaihi Wa Sallam terhadap umatnya. Ketiga, untuk menentukan klasifikasi hidup keislaman 
manusia, sehingga diketahui ada yang beriman dan bertakwa dan ada yang ingkar kepada ajaran Islam.

Hidayat, Rizal, \& Fahrudin (2018b) menemukan bahwa hasil evaluasi bisa dijadikan tolak ukur pendidikan untuk mengajar di semester selanjutnya, adapun untuk peserta didik, evaluasi tersebut bisa menjadi bahan intropeksi dalam belajar kedepannya supaya bisa lebih baik. Dengan demikian, Sari (2018) memastikan evaluasi dalam pendidikan Islam sangat erat kaitannya dengan apa yang telah difirmankan dalam Alquran, dimana objek yang dievaluasi dari peserta didik bukan hanya hal-hal yang berkaitan dengan aspek intelektual dan keagamaan saja, tetapi adanya keseimbangan antara keduanya. Peserta didik selalu dievaluasi tingkah laku keagamaan, sosial, keilmuan, keterampilan, dan lain sebagainya.

Berdasarkan uraian di atas, untuk memudahkan dalam memahami konsep dasar evaluasi dan implikasinya dalam evaluasi pembelajaran PAI di sekolah, dapat dibuatkan bagan sebagai berikut :

\begin{tabular}{|l|l|} 
Konsep \\
Dasar \\
Evaluasi \\
dan \\
Implikasi \\
nya \\
Dalam \\
Evaluasi \\
Pembelaja \\
ran \\
$\begin{array}{c}\text { Pendidika } \\
\text { n Agama } \\
\text { Islam di } \\
\text { Sekolah }\end{array}$
\end{tabular}

. Bagan 2 Konsep Dasar Evaluasi dan Implikasinya Dalam Evaluasi Pembelajaran Pendidikan Agama Islam di Sekolah 
E-ISSN: 2528-2476

\section{KESIMPULAN DAN SARAN}

Evaluasi dalam pembelajaran PAI harus dilakukan secara komprehensif dan terintegrasi. Kedudukan evaluasi sangat penting dalam pembelajaran PAI, karena evaluasi menempati posisi yang sangat sentral untuk mengetahui keberhasilan proses pembelajaran. Evaluasi dilakukan untuk mengetahui efektivitas dan efisiensi pembelajaran yang dilakukan, fungsinya untuk mengetahui kapasitas pendidik dan peserta didik, sehingga bisa dilakukan perbaikan jika memang ditemukan ada faktor yang belum optimal dalam proses pembelajaran. Kegunaan evaluasi dalam pembelajaran PAI untuk perbaikan, penyesuaian, dan penyempurnaan program berdasarkan pengalaman pendidik yang didapatkan di lapangan. Ruang lingkup evaluasi pembelajaran PAI mesti mencakup semua ranah, baik aqliyah, qolbiyah, dan amāliah. Prinsipnya harus kontinuitas, komprehensif, terintegrasi, adil, objektif, kooperatif, praktis, koherensi, dan akuntabilitas. Jenis evaluasinya mencakup evaluasi perencanaan, pengembangan, monitoring, efisiensi, dan program komprehensif.

Objek evaluasi pembelajaran untuk unsur-unsurnya meliputi input, transformasi, dan output. Ditinjau dari segi input adalah peserta didik. Dari segi transformasi terdiri dari kurikulum, metode, cara penilaian, sarana prasarana, sistem administrasi, guru, dan personal lainnya. Adapun dari segi output merupakan lulusan suatu sekolah. Adapun sebagai subjeknya adalah pendidik, kolaborasi dengan petugas yang sudah dibina (psikolog), dan guru mata pelajara lain, bahkan peserta didik juga bisa mengevaluasi diri sendiri. Teknik evaluasi PAI jangan hanya menggunakan teknik tes, tetapi harus kolaborasi dengan non-tes, karena untuk mengevaluasi pembelajaran PAI tidak cukup hanya menggunakan data-data yang terukur sebagaimana dalam teknik tes. Implikasinya, evaluasi pembelajaran Pendidikan Agama Islam di sekolah mesti dilakukan secara kontinuitas, komprehensif, dan terintegrasi. Dengan demikian, pendidik PAI harus mampu mengevaluasi tingkah laku perkembangan peserta didik dalam aspek aqliyah, qolbiyah, dan amāliyah. 


\section{DAFTAR PUSTAKA}

Aplikasi Quran in Word versi 64 - 3.0. (2018).

Arifin, Z. (2012). Evaluasi Pembelajaran : Prinsip Teknik Prosedur. Bandung: Remaja Rosdakarya.

Arikunto, S. (2003). Dasar-Dasar Evaluasi Pendidikan. Jakarta: Bumi Aksara.

Arikunto, S. (2013). Manajemen Penelitian. Jakarta: Rineka Cipta.

Daryanto. (2012). Evaluasi Pendidikan. Jakarta: Rineka Cipta.

Dudin, A. (2007). Evaluasi Pendidikan Agama Islam Pada SMP. EDUKASI: Jurnal Penelitian Pendidikan Agama Dan Keagamaan. Retrieved from https://jurnaledukasikemenag.org/index.php/edukasi/article/view/302/252

Gunawan, I. (2013). Metode Penelitian Kualitatif : Teori dan Praktik. Jakarta: Bumi Aksara.

Hanun, F. (2016). Evaluasi Penyelenggaraan Pendidikan Agama Islam (PAI) di Universitas Hasanuddin Makassar, Sulawesi Selatan. Jurnal Penamas, 29(3), 401418.

Hidayat, T., Rizal, A. S., \& Fahrudin. (2018a). Peran Pondok Pesantren Sebagai Lembaga Pendidikan Islam di Indonesia. Ta'dib : Jurnal Pendidikan Islam, VII(2), $1-15$. Retrieved from https://ejournal.unisba.ac.id/index.php/tadib/article/view/4117/2485

Hidayat, T., Rizal, A. S., \& Fahrudin. (2018b). Pola Pendidikan Islam di Pondok Pesantren Mahasiswa Miftahul Khoir Bandung Dalam Membentuk Kepribadian Islami. Ta'dib : Jurnal Pendidikan Islam, VII(1), 9-19. Retrieved from https://ejournal.unisba.ac.id/index.php/tadib/article/view/3770/2247

Hidayat, T., \& Suryana, T. (2018). Menggagas Pendidikan Islam : Meluruskan Paradigma Pendidikan di Indonesia. Jurnal Pendidikan Islam Indonesia, 3(1), 7591. Retrieved from http://ojs.pps-ibrahimy.ac.id/index.php/jpii/article/view/133/93

Hidayat, T., \& Syafe'i, M. (2018). Filsafat Perencanaan dan Implikasinya dalam Perencanaan Pembelajaran Pendidikan Agama Islam di Sekolah. Lentera Pendidikan, 21(2), 188-205. https://doi.org/https://doi.org/10.24252/lp.2018v21n2i5

Ismail, F. (2013). Inovasi Evaluasi Hasil Belajar Pendidikan Agama Islam (ModelModel Penilaian Berbasis Afektif). Ta'dib, XVIII(2), 228-259.

Mahmudi, I. (2011). CIPP: Suatu Model Evaluasi Program Pendidikan. Jurnal AtTa'dib, 6(1), 112-124. 
Miswanto. (2014). Evaluasi Pendidikan Agama Islam Berbasis Karakter. Jurnal Madaniyah, VII, 151-164.

Naima, \& Erniati. (2013). Evaluasi Pendidikan : (Perkembangan Moral Keagamaan Mahasiswa STAIN Datokarama Palu). Istiqra' : Jurnal Penelitian Ilmiah, 1(2), 239-258.

Nurharjadmo, W., \& Negara, J. A. (2008). Evaluasi Implementasi Kebijakan

Pendidikan Sistem Ganda di Sekolah Kejuruan. Spirit Publik, 4(2), 215-228.

Nuryamin. (2011). HAKIKAT EVALUASI: Perspektif Filsafat Pendidikan Islam. Lentera Pendidikan, 14(2), 202-218.

Purwanto. (2011). Evaluasi Hasil Belajar. Yogyakarta: Pustaka Pelajar.

Putra, S. R. (2013). Desain Evaluasi Belajar Berbasis Kinerja. Yogyakarta: DIVA Press.

Qowaid, \& Setianingsih, N. (2006). Evaluasi Diklat Guru Pendidikan Agama Islam Tingkat SMA. Jurnal Penelitian Pendidikan Agama Dan Keagamaan, 4(4), 158.

Raharjo, S. B. (2012). Evaluasi Trend Kualitas Pendidikan di Indonesia. Jurnal Penelitian Dan Evaluasi Pendidikan, 16(2), 298-319.

Ramadhan, S. (2017). Evaluasi Pendidikan Agama Islam di Madrasah Tsanawiyah Ibnul Qayyim Putri Yogyakarta. Jurnal Al-Thariqah, 2(1), 39-50.

RI, P. D. (2015). Al-Qur`an dan Terjemahnya. Bandung: Diponegoro.

Sari, L. M. (2018). Evaluasi Pendidikan Islam. Al-Tadzkiyyah : Jurnal Pendidikan Islam, 9(2), 211-231.

Sudijono, A. (2008). Pengantar Evaluasi Pendidikan. Jakarta: Rajagrafindo Persada.

Sukardi. (2011). Evaluasi Pendidikan Prinsip dan Operasionalnya. Jakarta: Bumi Aksara.

Supriadi, G. (2009). Evaluasi Pembelajaran Pendidikan Agama Islam Di SMA Negeri Se Kota Palangka Raya. Jurnal Studi Agama Dan Masyarakat, 3(20), 84-95.

Syafri, Z. (2016). Analisis Evaluasi Pembelajaran Pendidikan Agama Islam SMA Negeri 1 Rambatan, Tanah Datar. Jurnal Al-Fikrah, IV(2), 187-197.

Syahrul. (2007). Konsep Evaluasi Pendidikan dalam Perspektif Al Qur'an. Jurnal Hunafa, 4(4), 305-320.

Tayibnapis, F. Y. (2008). Evaluasi Program dan Instrumen Evaluasi untuk Program Pendidikan dan Penelitian. Jakarta: Rineka Cipta. 
Al-Tadzkiyyah: Jurnal Pendidikan Islam, Volume 10. No. I 2019 P. ISSN: 20869118

E-ISSN: 2528-2476

Wijaya, A., \& Sumarno. (2017). Evaluasi Dampak Pendidikan dan Pelatihan Pengembangan Keprofesian Berkelanjutan Guru Matematika di PPPPTK Matematika Yogyakarta. Jurnal Penelitian Dan Evaluasi Pendidikan, 21(2), 127141.

Yusuf, A. M. (2015). Asesmen dan Evaluasi Pendidikan Pilar Penyedia Informasi dan Kegiatan Pengendalian Mutu Pendidikan. Jakarta: Kencana Prenada Media Group. 